\title{
KHẢO SÁT CHỈ Số TIM-CỔ CHÂN VÀ MỐI LIÊN QUAN VỚI MỘT SỐ ĐĂC ĐIỂM LÂM SÀNG, CẬN LÂM SÀNG BỆNH NHÂN THÂ̂N NHÂN TẠO CHU KỲ
}

\author{
Nguyễn Văn Tuyên ${ }^{1}$, Bùi Mỹ Hạnh ${ }^{2}$, Lê Việt Thắng ${ }^{3}$
}

\section{TÓM TẮT}

Mục tiêu: Khảo sát chỉ số tim - chân (CAVI) và mối liển quan với một số đặc điểm lâm sàng, cận lâm sàng bệnh nhân thận nhân tạo chu kỳ. Đối tượng và phương pháp: Nghiên cứu mô tả cắt ngang 111 bệnh nhân thận nhân tạo chu kỳ và 88 người bình thường có cùng độ tuổi, giới. Tất cả các đối tượng đều được đo chỉ số CAVI. Kết quả: Chỉ số CAVI trung bình ở bệnh nhân thận nhân tạo chu kỳ là $9,96 \pm 2,14$, cao hơn những người bình thường là $8,14 \pm 0,59, \mathrm{p}<$ 0,001 . Có tới $66,7 \%$ bệnh nhân tăng chỉ số CAVI so nhóm chứng. Nhóm bểnh nhân tuổi $\geq 60$; thời gian TNT $\geq 5$ năm; mất chức năng thận tồn dư; đái tháo đường; THA có giá trị trung bình và hoăc tỷ lê tăng chỉ số CAVI cao hơn nhóm bệnh nhân không có đặc điểm trên, $p<0,05$. Chỉ số CAVI có mối tương quan thuận, mức độ không chặt với thời gian TNT, $r=0,247$, $p<0,01$. Kết luận: Tăng chỉ số CAVI là thường gặp ở bệnh nhân thận nhân tạo chu kỳ và có liên quan với tuổi cao, thời gian TNT kéo dài, mất chức năng thận tồn dư, ĐTĐ và THA

Tứ khóa: Bệnh thân man giai đoạn cuối, thận nhân tạo chu kỳ, Chỉ số tim-cổ chân, Đái tháo đường

\section{SUMMARY \\ SURVEY OF CARDIO-ANKLE VASCULAR INDEX AND RELATIONSHIP WITH CLINICAL, SUBCLINICAL CHARACTERISTICS IN PATIENTS TREATING WITH MAINTENANCE HEMODIALYSIS}

Objective: To investigate Cardio-Ankle Vascular Index (CAVI) and its relationship with some clinical and subclinical characteristics of patients with regular hemodialysis. Subjects and methods: A crosssectional descriptive study of 111 maintenance hemodialysis patients and 88 normal people of the same age and sex. All subjects were measured CAVI index. Results: The average CAVI index in hemodialysis patients was $9.96 \pm 2.14$, higher than that of normal people $(8.14 \pm 0.59), \mathrm{p}<0.001$. Ratio of increased CAVI compared with the control group was $66.7 \%$. The patients with age $\geq 60$ years old; hemodialysis time $\geq 5$ years; loss of residual renal function; diabetes mellitus; hypertension had mean CAVI and/or ratio of increase CAVI was higher than those of the patients without the above characteristics, $p<0.05$. The CAVI has a positive correlation with the

${ }^{1}$ Bệnh viện đa khoa Đức Giang, Hà Nội

2Trường Đại họ Y Hà Nội

33ệnh viện Quân y 103, Học viện Quân y

Chịu trách nhiệm chính: Nguyễn Văn Tuyên

Email: tuyenbvdkdg@gmail.com

Ngày nhận bài: 3/5/2021

Ngày phản biên khoa hoc: 25/5/2021

Ngày duyệt bài: 16/6/2021 duration of hemodialysis, $r=0.247, \mathrm{p}<0.01$. Conclusion: Increased CAVI is common in hemodialysis patients and it related to old age, prolonged duration of hemodialysis, loss of residual renal function, diabetic mellitus and hypertension.

Keywords: End-stage chronic kidney disease, Maintenance hemodialysis, Cardio-Ankle Vascular Index, diabetic mellitus.

\section{I. ĐẶT VẤN ĐỀ}

Bênh lý tim mach là môtt trong những vấn đề sức khỏe được quan tâm hàng đầu trên toàn thế giới với hậu quả nặng nề là tử vong, tàn phế và giảm sút chất lượng cuộc sống. Tỉ lệ tử vong tim mạch cũng chiếm ưu thế ở bệnh nhân suy thận, chiếm tới hơn $50 \%$ ở số các bênh nhân được điều trị bằng các phương pháp thay thế thận khác nhau, kể cả ở bệnh nhân được ghép thận [1],[2]. Độ cứng thành mạch tăng gây ra những biến cố tim mạch: nhồi máu cơ tim, đột quị não... Chỉ số tim - mắt cá chân (Cardio-Ankle Vascular Index - CAVI) là một thông số đánh giá đô cứng động mach hiêu quả và không xâm nhập, đó là chỉ số, được nhiêuu tác giả trên thế giới khuyến cáo sử dụng trên lâm sàng cho các bệnh nhân mắc bệnh mạn tính trong đó có bệnh nhân loc máu chu kỳ [3],[4]. Hiên tai, ở Viêt Nam chưa có nghiên cứu nào về chỉ số CAVI ở bệnh nhân bệnh thận mạn có và chưa có lọc máu. Vì vậy, chúng tôi thực hiện đề tài này với mục tiêu: Khảo sát chỉ số tim-cổ chân (CAVI) và mối liên quan với một số đăc điểm lâm sàng, cânn lâm sàng ở bệnh nhân thận nhân tạo chu kỳ.

\section{II. ĐỐI TƯỢNG VÀ PHƯƠNG PHÁP NGHIÊN CỨU}

1. Đối tượng nghiên cứu. Gồm 199 đối tượng, được chia làm 2 nhóm:

- Nhóm bênh: Là 111 bệnh nhân được chẩn đoán bệnh thận mạn giai đoạn cuối được lọc thận nhấn tạo chu kỳ, tại Bệnh viện đa khoa Đức Giang, Hà Nội.

- Nhóm chứng: Là 88 người bình thường có độ tuổi, giới tương đương nhóm nghiên cứu.

- Tiêu chuẩn lựa chọn

+ Tiêu chuẩn lựa chọn bệnh nhân nghiên cứu: Các bệnh nhân đang chạy thận nhân tạo tại khoa Nội thận-Tiết niệu, Bệnh viện đa khoa Đức Giang, tuổi $\geq 18$ tuổi, thời gian lọc máu $\geq 3$ tháng, đồng ý tham gia nghiên cứu.

+ Tiêu chuẩn lựa chọn nhóm chứng: Người bình thường đến khám sức khỏe định kỳ có độ 
tuổi tương đương với bệnh nhân trong nhóm nghiên cứu, đồng ý tham gia nghiên cứu.

- Tiêu chuấn loai trừ

+ Bênh nhân đang trong tình trạng viêm phổi, sốt...

+ Đang nghi ngờ mắc bệnh ngoại khoa

+ Mắc ung thư kèm theo

+ Đo chỉ số CAVI kết quả hỏng

2. Phương pháp nghiên cứu

- Nghiên cứu mô tả cắt ngang, có so sánh với nhóm chứng người bình thường.

- Cỡ mẫu nghiên cứu: lấy mẫu thuận tiện

- Tất cả các bệnh nhân đang lọc máu bằng thận nhân tạo chu kỳ tại Bệnh viện đa khoa Đức giang đủ tiêu chuẩn chọn được đưa vào nghiên cứu.

- Hỏi và khám phát hiện các triệu chứng và dấu hiệu lâm sàng

- Lấy máu tĩnh mạch lúc đói làm các xét nghiệm huyết học và sinh hoá

- Tất cả 199 đối tượng được đo CAVI theo kỹ thuật sau:

+ Nhóm bệnh nhân được đo trước cuộc lọc máu 30 phút, nhóm chứng đo khi lấy đi khám được kết luận khoẻ mạnh.

+ Bệnh nhân được nghỉ ngơi ít nhất 10 phút trước khi đo. Bênh nhân được đo ở tư thế nằm ngửa trên giường, tay chân duỗi thẳng, thả lỏng cơ bắp, không cử động, không nói chuyện trong quá trình đo.

+ Nhập các thông tin về bệnh nhân vào máy: Gồm mã bệnh án, họ tên, tuổi, giới, huyết áp, chiều cao, cân nặng, các thuốc đã dùng và triệu chứng lâm sàng.

+ Quá trình đo sẽ được máy thực hiện một cách tự động. CAVI được máy tự động tính toán dựa trên huyết áp, thời gian lan truyền sóng mạch theo một thuật toán đặc biệt.

+ Kết quả gồm CAVI bên phải, bên trái được hiển thị trên màn hình, nghiên cứu lấy CAVI bển phải (Bên không có cầu tay).

+ Đánh giá biến đổi chỉ số CAVI dựa vào kết quả nhóm chứng thường: Giá trị CAVI nhóm bệnh được cho là bình thường khi nằm trong khoảng $X \pm 2 S D$ nhóm chứng. Với giá trị nhóm bệnh $>X+2 S D$ được coi là tăng chỉ số CAVI.

- Xử lý số liệu bằng phần mềm SPSS 20.0

\section{KẾT QUẢ NGHIÊN CỨU}

Nhóm bênh có tuổi trung bình là 55,22 \pm 13,74 tuổi, nam chiếm 49,5\%, thời gian TNT trung bình là 30 tháng (13-74).

Bảng 3.1. So sánh chi số CAVI nhóm bệnh và chứng

\begin{tabular}{|l|l|l|l|}
\hline Đặc điếm & Nhóm & Nhóm & p \\
\hline
\end{tabular}

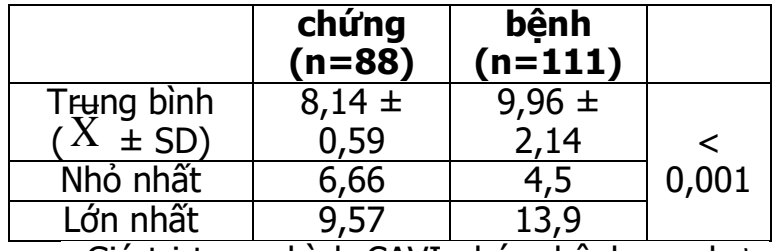

- Giá trị trung bình CAVI nhóm bệnh cao hơn nhóm chứng, $\mathrm{p}<0,001$.

$33,3 \%$

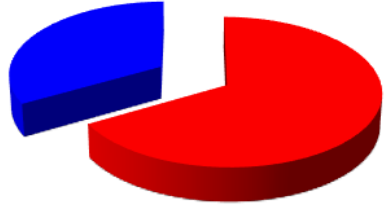

$66,7 \%$

$$
\text { - Tăng } \quad \text { Không tăng }
$$

Biểu đồ 3.1. Tỷ lệ tăng chỉ số CAVI ( $n=111)$

Nhận xét: Tăng chỉ số CAVI là phổ biến, chiếm $66,7 \%$ bênh nhân TNT chu kỳ.

Bảng 3.2. Liên quan chi số CAVI với tuổi và giới

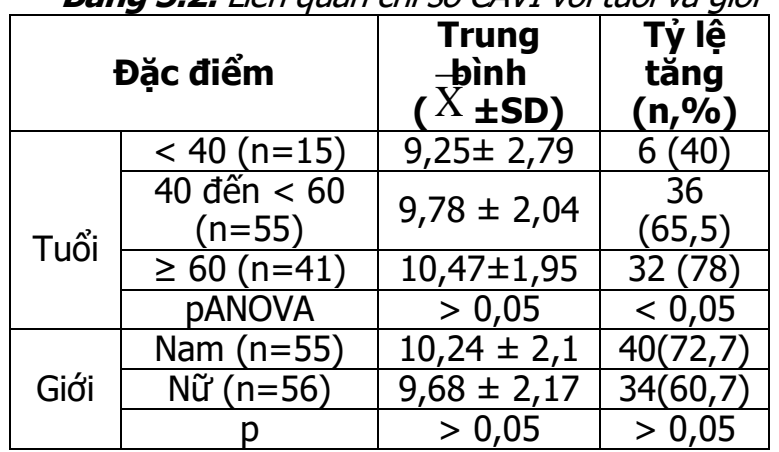

- Không có liên quan giữa chỉ số CAVI với giới, tuy nhiên bệnh nhân tuối cao có chỉ số CAVI cao hơn nhóm tuổi trẻ hơn có ý nghĩa, $\mathrm{p}<0,05$.

Bảng 3.3. Liên quan với thời gian thận nhân tạo và chức năng thận tồn dư

\begin{tabular}{|c|c|c|c|}
\hline \multicolumn{2}{|c|}{ Đặc điểm } & \multicolumn{2}{|c|}{\begin{tabular}{c|c} 
Trung bình & Tỷ lệ tăng \\
$(\mathrm{X} \pm \mathrm{SD})$ & $(\mathrm{n}, \%)$ \\
\end{tabular}} \\
\hline \multirow{3}{*}{$\begin{array}{l}\text { Thời } \\
\text { gian } \\
\text { TNT }\end{array}$} & $\begin{array}{l}<5 \text { năm } \\
(n=75)\end{array}$ & $9,6 \pm 2,0$ & $46(61,3)$ \\
\hline & $\begin{array}{c}\geq 5 \text { năm } \\
(n=36)\end{array}$ & $\begin{array}{c}10,72 \pm \\
2,26\end{array}$ & $28(77,8)$ \\
\hline & & $<0,01$ & $>0,05$ \\
\hline \multirow{2}{*}{$\begin{array}{l}\text { Chức } \\
\text { năng thânn } \\
\text { tôn dư }\end{array}$} & \begin{tabular}{|l|} 
Mất $(n=88)$ \\
Còn $(n=23)$
\end{tabular} & \begin{tabular}{|l}
$10,31 \pm 1,97$ \\
$8,62 \pm 2,29$
\end{tabular} & $\begin{array}{l}64(72,7) \\
10(43,5)\end{array}$ \\
\hline & OR, $p$ & $<0,005$ & $\begin{array}{c}\mathrm{p}<0,01 \\
\mathrm{OR}=3,467\end{array}$ \\
\hline
\end{tabular}

- Nhóm bênh nhân có thời gian TNT từ 5 năm trở lên có chỉ số CAVI trung bình cao hơn nhóm bệnh nhân thời gian TNT $<5$ năm, $\mathrm{p}<0,01$. Nhóm bênh nhân mất chức năng thân tôn dư có tỷ lệ tăng CAVI gấp 3,467 lần so với nhóm còn chức năng thận tôn dư, $p<0,01$. 


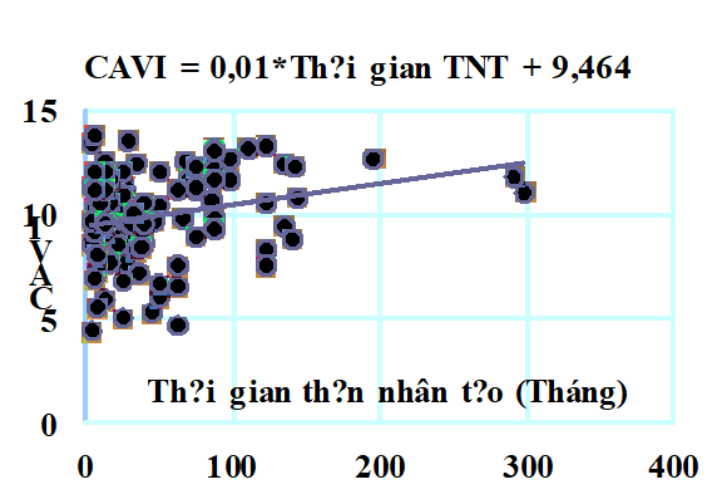

Biểu đồ 3.2. Tương quan chỉ số tim cổ chân với thời gian thận nhân tạo ở nhóm bênh $(n=111)$

Nhận xét: Chỉ số CAVI có mối tương quan thuận, mức độ không chặt với thời gian TNT, $r=0,247, p<0,01$.

Bảng 3.4. Liên quan với đái tháo đường và hút thuốc lá

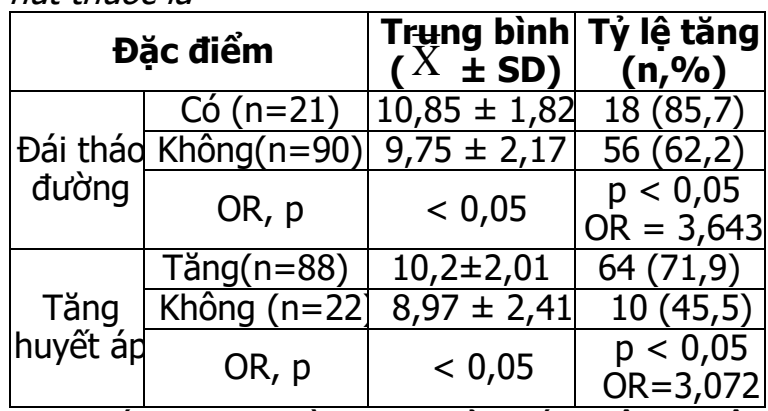

- Giá trị trung bình CAVI ở nhóm bênh nhân có ĐTĐ hoăc THA cao hơn lần lượt gấp 3,643 và 3,072 lần nhóm không có, $p<0,05$.

\section{BÀN LUÂN}

Chỉ số CAVI ở bênh nhân bênh thận mạn giai đoạn cuối thận nhân tạo chu kỳ cao hơn so với người bình thường, khi so sánh nhóm chứng chúng tôi thây có tới $66,7 \%$ bệnh nhân có chỉ số CAVI tăng. Kết quả này cũng tương tự trong nghiên cứu của các tác giả khác [3],[4]. Như vậy, ở những người bệnh có yếu tố nguy cơ xơ cứng mạch (suy thận, tăng huyết áp, bệnh mạch vành...), chỉ số CAVI đều cao hơn so với những người khỏe mạnh bình thường. Tuy nhiên, chỉ số CAVI trung bình trong nghiên cứu của chúng tôi thấp hơn trong các nghiên cứu của các tác giả Nhật Bản và cao hơn so với một số tác giả, do thời điểm đo CAVI khác nhau giữa các nghiên cứu. Chúng tôi đo trước cuộc lọc máu, và số liệu chỉ lấy bên phía không có cầu tay. Lọc máu làm giảm thể tích dịch cơ thể, từ đó làm tăng CAVI đặc biệt ở những bệnh nhân có tỷ lệ loại bỏ cao hởn (> 5\% trong lượng khô), vì vậy, sự khác biệt về thời điểm đo có thể ảnh hưởng đến kết quả ở bệnh nhân chạy thận nhân tạo [3].

Nhiều nghiên cứu cho thấy: chỉ số CAVI tăng tuyến tính theo tuổi. Các nghiên cứu khác cũng chỉ ra rằng độ cứng động mạch liên quan chặt chẽ với tuổi, yếu tố chính ảnh hưởng đến tính chất cơ học của động mạch. Kết quả nghiên cứu của chúng tôi cũng cho thây tỷ lệ BN tăng CAVI ở nhóm tuổi cao thì cao hơn nhóm tuổi thấp, $p<$ 0,05 . Có sự gia tăng độ cứng động mạch và huyết áp động mạch (tăng huyết áp tâm thu và giảm huyết áp tâm trương theo tuổi) theo tuổi ở cả quần thể khỏe mạnh và quần thể bị bệnh, ảnh hưởng của sự lão hóa khác nhau ở các động mạch trung tâm (độ đàn hồi), so với các động mạch ngoại vi (cơ bắp) và tiểu động mạch. Độ cứng của động mạch trung tâm tăng dần theo độ tuổi trong khi độ cứng của các động mạch ngoại vi ít thay đổi theo tuổi. Những kết quả này được báo cáo ở cả hai giới, mặc dù đường kính và chiều dài động mạch ở nữ thấp hơn ở nam giới [5].

Trong nghiên cứu chúng tôi thấy chỉ số CAVI liên quan đến thời gian TNT và chức năng thận tồn dư. Ở những bệnh nhân thời gian TNT từ 5 năm trở lên hoặc mất chức năng thận tồn dư thì chỉ số CAVI trung bình và tỷ lệ BN tăng chỉ số CAVI cao hơn nhóm bệnh nhân không có 2 đặc điểm trên. Thời gian TNT kéo dài liên quan đển mất chức năng thận tồn dư. Ở bệnh nhân TNT kéo dài xuất hiện nhiều yếu tố liển quan và là yếu tố nguy cơ của vữa xơ và cứng động mạch như: rối loạn lipid máu, rối loạn chuyển hoá canxi phospho, viêm... Những yếu tố này làm tăng hiện tương vữa xơ và làm nặng lên hiện tượng này [3],[6]. Việc duy trì chức năng thẩn tồn dư rất quan trọng để giảm các biến cố tim mạch, nâng cao chất lượng cuộc sống bệnh nhân TNT. Lợi ích của bảo tồn chức năng thận tồn dư được giả thuyết là nhờ sự kiểm soát thể tích, khoáng chất và chất điện giải được cải thiện, ít viêm hơn và thanh thải tốt hơn các chất hòa tan liên kết với protein và các phân tử trung bình. Chạy thận nhân tạo chỉ được áp dụng ngắt quãng, trong khi chức năng thận tự nhiển là liên tục. Vì lý do này, ngay cả một lượng nhỏ chức năng còn sót lại cũng làm giảm nồng độ trong huyết tương của các chất hòa tan kém bằng thẩm tách máu, chẳng hạn như các protein trọng lượng phân tử thấp như $\beta 2$-microglobulin và các chất hòa tan gắn với protein cũng như các chất khác bao gồm Hcy.

Cuối cùng chỉ số CAVI có liên quan đến ĐTĐ và THA. Cũng như với thời gian TNT và chức năng thận tồn dư, những bệnh nhân ĐTĐ; THA 
có giá trị trung bình chỉ số CAVI và tỷ lệ tăng cao hơn so với nhóm bệnh nhân không có đặc điểm này, $p<0,05$. Đái tháo đường là một yếu tố nguy cơ bệnh tim mạch, trong đó có vữa xơ mạch máu và các biến cố tim mạch. Tăng huyết áp và ĐTĐ cùng tồn tại ở 30-80\% bệnh nhân và làm tăng nguy cơ mắc bệnh tim mạch. Tăng huyết áp làm tăng nguy cở CAVI bất thường ở người bệnh ĐTÐ với nguy cơ tương đối gấp 2,43 lần so với người khỏe mạnh. Trong bệnh ĐTÐ, cơ chế chính của việc tăng độ cứng động mạch là tăng cường tạo ra và tích tụ các sản phẩm cuối glycation tiên tiến (AGEs) trong thành mạch, gây ra liên kết chéo quá mức giữa AGEs và các phân tử collagen của chất nền ngoại và dẫn đến dày lớp nội trung mạc và làm cứng thành động mạch. Trong tăng huyết áp, xơ cứng động mạch xảy ra do tăng áp lực nội mạc gây ra cắng thẳng dễ rung động tăng dẫn đến suy thoái elastin và kích thích sản xuất collagen. Những đặc điểm này làm chỉ số CAVI cao hơn.

\section{KẾT LUÂN}

- Chỉ số CAVI trung bình ở bệnh nhân thân nhân tạo chu kỳ là $9,96 \pm 2,14$, cao hơn những người bình thường là $8,14 \pm 0,59$, có ý nghĩa $p<$ 0,001. Có tới $66,7 \%$ bệnh nhân tăng chỉ số CAVI so nhóm chứng.

- Nhóm bệnh nhân tuổi $\geq 60$; thời gian TNT $\geq 5$ năm; mất chức năng thận tồn dư; đái tháo đường; THA có giá trị trung bình và hoặc tỷ lệ tăng chỉ số CAVI cao hơn nhóm bênh nhân không có đặc điểm trên, $p<0,05$. Chỉ số CAVI có mối tương quan thuận, mức độ không chặt với thời gian TNT, $r=0,247, p<0,01$.

\section{TÀI LIÊU THAM KHẢO}

1. Chen J, Budoff MJ, Reilly MP, et al. (2017). Coronary Artery Calcification and Risk of Cardiovascular Disease and Death Among Patients With Chronic Kidney Disease. JAMA Cardiol. 2(6):635-643.

2. Thomas R., Kanso A., Sedor J.R. (2008). Chronic kidney disease and its complications. Prim Care, 35(2): $329-32$.

3. Ichihara A, Yamashita $N$, Takemitsu $T$, et al. (2008). Cardio-ankle vascular index and ankle pulse wave velocity as a marker of arterial fibrosis in kidney failure treated by hemodialysis. Am J Kidney Dis, 52(5), 947-955.

4. Kato A, Takita T, Furuhashi $M$, et al. (2012). Brachial-Ankle Pulse Wave Velocity and the CardioAnkleVascular Index as a Predictor of Cardiovascular Outcomesin Patients on Regular Hemodialysis. Therapeutic Apheresis and Dialysis 16 (3): 232-241.

5. Takenaka T, Hoshi $H$, Kato $N$, et al (2008). Cardio-Ankle Vascular Index to Screen Cardiovascular Diseases in Patients with End-Stage Renal Diseases. J Atheroscler Thromb 15: 339-44.

6. Jeznach-Steinhagen A, Słotwiński R, Szczygieł B. (2007). Malnutrition, inflammation, atherosclerosis in hemodialysis patients. RocZ Panstw Zakl Hig. 58(1):83-8.

7. Nagayama D., Saiki A., Endo K., Yamaguchi T., et al. (2010). Improvement of cardio-ankle vascular index by glimepiride in type 2 diabetic patients. Int J Clin Pract, 64(13), pp. 1796-1801.

8. Takafumi Okura, Sanae Wanatabe, et al. (2007). Relationship betwen cardio ankle vascular index (CAVI) and carotid atherosclerosis in patients with essential hypertension. Hypertens Res 30 (4): 335-340.

\section{KHẢO SÁT HÌNH THÁI VÀ LIÊN QUAN VỚI CẤU TRÚC CÂN BÊN CỦA XOANG BƯỚM TRÊN PHIM CHỤP CẮT LỚP VI TÍNH ĐA DÃY}

\section{TÓM TẮT}

Mục tiêu; Khảo sát hình thái và liên quan với các cấu trúc cận bên của xoang bướm trên phim chụp cắt lớp vi tính đa dãy (CLVT). Đối tướng và phương pháp: Gồm 60 bệnh nhân (BN) (tuổi từ 18 đến 92), nam chiếm $35 / 60 \quad(58,3 \%)$ và nữ chiếm $25 / 60$ $(41,7 \%)$ được chụp CLVT đa dãy sọ não tại Bệnh viện Việt Đức Hà Nội, được xử lý bằng phầm mềm Radiant

\footnotetext{
${ }^{1}$ Trường Đai hoc Y Dướ Thái Bình

Chịu trách nhiệm chính: Vũ Duy Tùng

Email: tunganatomy@gmail.com

Ngày nhận bài: 18/4/2021

Ngày phản biên khoa họ: 15/5/2021

Ngày duyệt bài: 12/6/2021
}

Vũ Duy Tùng ${ }^{1}$, Trần Thị Hằng ${ }^{1}$

khảo sát dưới 3 măt phẳng (MP) tái taoo. Chúng tôi khảo sát các loại khí hóa xoang bướm mở rộng: dốc nền, ngách bên, cánh nhỏ, Iõm trước và sự lồi, mất thành xương (phơi trân) của các cấu trúc động mạch cảnh trong (ĐMCT), thần kinh thị giác (TKTंG), thần kinh hàm trên (TKV2) và thần kinh Vidian (TKVidian) vào xoang bướm. Kết quả: $100 \%$ bệnh nhân quan sát đước xoang bướm rõ nét trên phim. Tỷ lệ loai khí hóa mở rộng ngách bên và dốc nền đều là $63,3 \%$, loại cánh nhỏ là $30 \%$ và loai Iõm trước là $20 \%$. Đông mạch cảnh trong lồi vào xoang bướm $71,7 \%$, phới trần $10 \%$. Thần kinh thi giác lồi vào xoang bướm $49,2 \%$, phơi trân $7,5 \%$, Thần kinh hàm trên lồi vào xoang bướm $37,5 \%$, phơi trần 3,3\%. Thần kinh vidian lồi vào xoang bướm 44,2\%, phơi trân 19,2\%. Theo thống kê có sự liên quan giữa khí hóa mở rộng sang 